\title{
Socio-Economic, Psychological Profile and Constraints Faced by the KVK Adopted Farmers for Improved Rice Cultivation in West Garo Hills District
}

\author{
S. Medhi ${ }^{*}$, A.K. Singha ${ }^{2}$, R. Singh ${ }^{3}$ and R.J. Singh ${ }^{3}$ \\ ${ }^{1}$ Krishi Vigyan Kendra, Ri Bhoi, ICAR RC for NEH Region Umiam, Meghalaya, India \\ ${ }^{2}$ ATARI Zone-VII, ICAR RC for NEH Region, Umiam, Meghalaya, India \\ ${ }^{3}$ College of Post Graduate Studies, CAU, Umiam, Meghalaya, India \\ *Corresponding author: samirmedhi1993@gmail.com (ORCID ID: 0000-0003-0274-2692)
}

Received: $11-04-2020$

Revised: $18-07-2020$

Accepted: 24-08-2020

\begin{abstract}
The study on socio-economic and psychological profile of the KVK adopted farmers of improved rice cultivation practices was conducted in West Garo Hills district of Meghalaya with 120 sample size from the adopted villages. Data collection was done with the help of pre-tested structured schedule through personal interview method. The majority of the respondents in adopted villages belonged to middle age category and medium level of education, nuclear family type and medium size of family with medium level of social participation. They engaged farming as primary occupation and had operational land holding size up to 1 ha with income level ranging from ₹ 25,900.00 to ₹ 1, 65,067.00. Most of the beneficiary farmers had farming experience between the ages of 18 to 38 years, received medium level of trainings, financial credit facility from government sources. The beneficiary had medium level of economic motivation, information seeking behaviour, decision-making ability, innovation proneness and attitude towards KVK with high level of market orientation and risk orientation. The study further indicates that among the various problems identified by the respondents, inadequate availability of quality seed at proper time was highlighted as the major problem by the rice cultivators.

\section{Highlights}

0 Majority of the respondents belonged to middle age category and medium level of education, family size and nuclear family type.

( Farming is the primary occupation with income level ranging from ₹ $25,900.00$ to ₹ $1,65,067.00$ with farming experience between the age of 18 to 38 years.

( The beneficiary had medium level of economic motivation, information seeking behavior, decision making ability, innovation proneness and attitude towards KVK with high level of market orientation and risk orientation.

( Inadequate availability of quality seed at proper time was highlighted as the major problem by the rice cultivators.
\end{abstract}

Keywords: Socio-economic, Psychological, Profile, Adopted, Farmers, Villages

Agriculture sector comprising of crops and livestock enterprises has been playing a vital role in reducing rural as well as aggregate poverty, socioeconomic advancement and sustainable economic development in the country through the gradual improvement of rural economy (Singha et al. 2016).
Over $58 \%$ of the rural households in the country depend on agriculture as their principal means of

How to cite this article: Medhi, S., Singha, A.K., Singh, R. and Singh, R.J. (2020). Socio-Economic, Psychological Profile and Constraints Faced by the KVK Adopted Farmers for Improved Rice Cultivation in West Garo Hills District. Economic Affairs, 65(3): 379-388.

Source of Support: None; Conflict of Interest: None 
livelihood. As per estimates by the Central Statistics Office (CSO), the share of agriculture and allied sectors (including agriculture, livestock, forestry and fishery) was $16.1 \%$ of the Gross Value Added (GVA) during 2014-15 at 2011-12 prices and the gross capital formation in agriculture, which was $18.3 \%$ of agri-GDP in $2012-13$ has fallen to $14.8 \%$ in 2014-15 (Economic Survey 2015). In North East Region, agriculture along with its allied sectors such as animal husbandry and fisheries is the largest sector of the rural economy and is the main source of livelihood and income security of the rural population. Agriculture provides livelihood support to $70 \%$ of region's population in the region which produces only $1.5 \%$ of country's food grain production and continues to be a net importer of food grains even for its own consumption (Singha et al. (2016)). Agricultural land including fallow in the region is $22.20 \%$ (varying between $37.43 \%$ in Assam and $4.40 \%$ in Arunachal) as against 54.47\% in India. Cultivators (41.61\%) and agricultural labourers $(13.07 \%)$ together constitute the majority of the workforce as against $31.65 \%$ and $26.55 \%$ respectively in India (Singha et al. 2016). Land distribution is mostly egalitarian rooted in the principle of community way of living and sharing. However, the area available under cultivable land for agriculture in the region also continues to decrease due to the rapid economic development, which occupies more agricultural land mainly for housing, business and industrial purposes. The region suffers from weaknesses such as subsistence agriculture with poor infrastructure like roads and markets. The high vulnerability to natural calamities like floods, submergence, landslides, soil erosion, etc. has resulted in low and uncertain agricultural productivity. The low utilization of modern inputs in agriculture has further reduced the ability of the farm households to cope with high risks in production and income (Singha et al. 2016). Past studies recognise that unique socio-economic, personal and psychological characteristics of the farmers have significant influences towards adoption of any agricultural technology in different farming systems. Their key environmental and socio-economic factors have significant influence towards adoption and diffusion of agriculture technologies (Lestrelin et al. 2012). The socio-economic characteristics of farmers and farm are important for better policy options (Tani
Net $2^{\text {nd }}$ Report 2000). Generally the socioeconomic approach focuses on identifying the adaptive capacity of individuals or communities based on their internal characteristics such as, education, gender, wealth, health status, access to credit, access to information and technology, formal and informal (social) capital, political power, and so on (Alam et al. 2010). Variations of these factors are responsible for the variations in socio-economic characteristics of farmers. It influences the accessibility to the resources, livelihood pattern, food and nutritional security etc. (Roy et al. 2013). Any farming or nonfarming activity is interdependent with the socioeconomic status of the individual and it could be considered both the cause and effect of farming (Kumar et al. 2007). Therefore, understanding of the socio-economic and personality traits of the farmers who are engaging improved practices of both crops and livestock enterprises and their problems in meaningful adoption of the practices in their farming systems will certainly help in accelerating the process of effective transfer of technology as because it largely affects the adoption process. Hence, it was felt imperative to study the socio-economic and psychological status of the farmers in the region in order to have a holistic approach for the agricultural development of the villages, ultimately leading to the socio-economic development of the farming community in the region.

\section{MATERIALS AND METHODS}

\section{Location of the study}

West Garo Hills district was purposively selected for the study. Six adopted villages namely Dengasi, Horipur, Bhaitbari Marapara, Rongbokgre and Sananggre were selected purposively from two blocks (Selsella and Dalu) having the maximum number of trained farmers under KVK West Garo Hills, Meghalaya.

\section{Selection of farmer respondents}

A complete list of trainee farmers who had participated in at least five training programmes conducted by Krishi Vigyan Kendra, West Garo Hills, was prepared in consultation with the staff of the KVK. Selection of trainees from each selected and adopted villages was done proportionately. 
From each selected village, respondents were selected proportionately, thus constituted 120 as the final size of the sample.

\section{Data base and methodology}

The study was conducted in West Garo Hills district of Meghalaya during the year 2016-17 by the researchers as part of the M. Sc. (Agril. Extension) degree programme under College of Post-Graduate Studies of Central Agricultural University, Imphal, Umiam, Meghalaya. The selected respondents were personally approached and interviewed at their place of residence/ field by the investigators along to get the responses were carefully recorded in the schedule. The independent variables such as Age, Education, Family Size, Family type, Social participation were measured with the help of scales developed by (Trivedi and Pareek 1964), structured schedule and social participation scale developed by (Sulthana 2001) with slight modification. The socio-economic variables size of operational land holding, annual income of family, credit facility, farming experience and training received were measured with the help of schedules structured for the purpose. The psychological variables namely; economic motivation, market orientation, information seeking behavior, decision making ability, risk orientation and innovation proneness were measured with the scales developed by (Singha 1991), (Samantha 1997) followed by Singha (2000), Moulasab (2004), Gajendra (2012) and Parvathamma (2012) respectively. To measure the attitude towards KVK procedure followed by (Dubey et al. 2008) was used. Simple statistical tools like frequency, percentage, mean and standard deviation were used for analysis and interpretation of data. The respondents were divided into low, medium and high categories on the basis of mean and standard deviation as adopted by (Dasgupta 1989).

\section{RESULTS AND DISCUSSION}

\section{Personal characteristics}

Age: It is noticed that, 52.50 per cent of trained farmers belonged to the middle age group ranging from 36-50 years, followed by old age (42.50\%) with age from 51-72 years and young age group $(5.00 \%)$ with age from $27-35$ years. This indicates that middle and old age farmers preferred more than young farmers in rice farming activities. The youth in general were interested in government jobs, business and other occupation compared to farming activities. The findings are in conformity with that of studies conducted by Shashidhara (2006) and Mangala (2008).

Education: With regard to level of education, majority respondents (43.33\%) had medium level of formal education attaining either, high school or secondary standard. This was followed by high level $(31.67 \%)$ with graduate diploma or above and low level $(23.33 \%)$ in standards of primary or middle school. Only 1.67 per cent respondents were found to have no education from any of the formal educational institution. This indicates that farmers, by and large, in study area were found having medium to high level of education, possibly due to realization of importance of formal education by the respondents' parents and the increase importance of literacy and facilities available. The other factors attributed to this were availability of good numbers of school in nearby towns with transportation and communication facilities. The findings are supported by that of Gohain (2006).

Family size: Majority of the trainee respondents were from medium family group (70.00\%) with 4-6 members followed by large family group (21.67\%) with 7 members and above and small family group $(8.33 \%)$ with up to 3 members only. The findings are in conformity with that of study conducted by Beerannarai (1995).

Family type: It is noticed that, 56.67 per cent of the trained farmers belonged to nuclear family category. Whereas, 43.33 per cent belonged to joint family category. This might be due to changing value of family system and modernization. The results are in line with the findings reported by Deshmukh and Mane (1999) and Sridhara (2002).

Social participation: Among the sampled farmers studied, 54.16 per cent of them had medium level of social participation followed by 33.33 per cent with high level and 12.50 per cent of the farmers having low level of social participation. This is due to the reason that farmers understood the importance of social life and activities to build them up in a society. So they actively participated in extension programmes and activities organized at the village. It was found that majority of the 
$\underset{\text { AESSRA }}{\sqrt{U}}$ Medhi et al.

farmers with medium and high level of social participation when informed actively participated in training programmes, nokma meetings and even clan meetings. The findings are in conformity with the findings of Balakrishnan (2001).

Table 1: Distribution of respondents according to their socio-personal characteristics

\begin{tabular}{|c|c|c|c|c|c|}
\hline S1. & Socio per & sonal varia & ables $n=12$ & & \\
\hline A. & Age & & & & \\
\hline & Category & $\begin{array}{l}\text { Frequen- } \\
\text { cy (f) }\end{array}$ & $\begin{array}{l}\text { Percent- } \\
\text { age (\%) }\end{array}$ & Mean & S.D. \\
\hline 1. & Young (27-35 years) & 6 & 5.00 & & \\
\hline 2. & Middle (36-50 years) & 63 & 52.50 & 50.20 & 9.06 \\
\hline 3. & Old (51-72 years) & 51 & 42.50 & & \\
\hline B. & Education & & & & \\
\hline 1. & No education $(0)$ & 2 & 1.67 & & \\
\hline 2. & Low (1-2) & 28 & 23.33 & & \\
\hline 3. & Medium (3-4) & 52 & 43.33 & 3.53 & 1.25 \\
\hline 4. & High (5-6) & 38 & 31.67 & & \\
\hline C. & Family size & & & & \\
\hline 1. & $\begin{array}{l}\text { Small } \\
\text { (Up to } 3 \text { members) }\end{array}$ & 10 & 8.33 & & \\
\hline 2. & Medium & 84 & 70.00 & & \\
\hline 3. & $\begin{array}{l}\text { (4-6 members) } \\
\text { Large } \\
\text { ( } 7 \text { members and } \\
\text { above) }\end{array}$ & 26 & 21.67 & 2.13 & 0.54 \\
\hline D. & Family type & & & & \\
\hline 1. & Joint & 52 & 43.33 & 156 & 0 \\
\hline 2. & Nuclear & 68 & 56.67 & 1.56 & 0.49 \\
\hline E. & Social participation & & & & \\
\hline 1. & Low (9-11) & 15 & 12.50 & & \\
\hline 2. & Medium (12-20) & 65 & 54.16 & 15.57 & 4.64 \\
\hline 3. & High (21-27) & 40 & 33.33 & & \\
\hline & Total & 120 & 100 & & \\
\hline
\end{tabular}

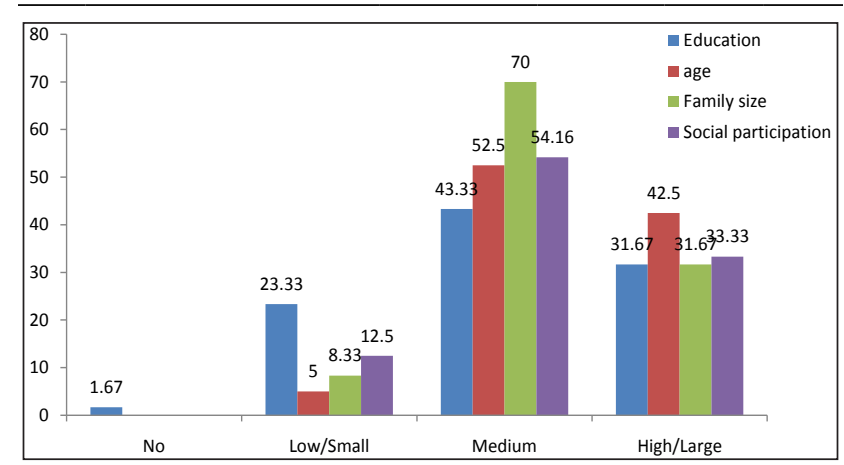

Fig. 1: Diagrammatic presentation of respondents according to their socio-personal characteristics

\section{Economic characteristics}

Size of operational land holding: The data presented in Table 2 show that majority $(70.83 \%)$ of the respondents were marginal farmers possessing land holding size of up to 1.0 hectare with the prevailing cultural/traditional norms of distribution of the parental land property among the sons followed by small farmers $(27.50 \%)$ with land holding between 1.01 to 4.0 hectares. Only $1.67 \%$ respondents belonged to the high category of land holding size (above 4.0 ha). The results were in line with the results of Balakrishnan (2001).

Annual income: It can be observed from the table that as many as 87.50 per cent respondents belonged to medium category of annual income from all sources which ranged from ₹ 33,281 to $₹ 1,65,066$. This was followed by high category (10.00\%) with income above ₹ 1, 65, 066 and low $(2.50 \%)$ with income less than ₹ 33, 281 per year. It is learnt that most of the farmers in the study area engaged in different non-farm activities as per their occupation more than agricultural activities for ensuring regular employment and income. The results were in conformity with the results of the studies conducted by Raghavendra (2005) and Reddy (2006).

Farming experience: It is revealed from the table that, 52.00 per cent of trained farmers belonged to medium experience category, followed by high experience $(40.00 \%)$ and low experience category $(8.00 \%)$. Majority of the trained farmers belonged to marginal land holding category i.e. land holding (up to $1.0 \mathrm{ha}$ ) and also majority of the trained farmers were educated up to middle school therefore, majority of the respondents belonged to medium experience category. The findings were in conformity with the findings of Gopalswamy and Anbarashan (2011).

Training received: From the table it can be seen that most of the respondents had medium level of training $(64.17 \%)$ followed by low $(35.83 \%)$ and no respondents were found in the high level category. Most of the respondents had medium level of education and medium level of attitude towards KVK training; this might be the probable reason for medium level of training by majority of the trained farmers. The findings were in conformity with the findings of Singha et al. (2016). 
Credit facility: Table indicates that 68.33 per cent of the respondents' got financial assistance from government for rice cultivation, while 44.16 per cent, 12.50 per cent and 25.84 per cent of the rice growers took credit from various formal and non-formal sources like bank, money lenders and friends/relatives, respectively. The findings were in conformity with the findings of Singha et al. (2016).

Table 2: Distribution of respondents according to their economic characteristics

\begin{tabular}{|c|c|c|c|c|c|}
\hline $\begin{array}{l}\text { Sl. } \\
\text { No. }\end{array}$ & Socio-e & conomic va & ariables $n=$ & $=120$ & \\
\hline A. & Size of operation & al land hold & ding & & \\
\hline & Category & $\begin{array}{l}\text { Frequen- } \\
\text { cy (f) }\end{array}$ & $\begin{array}{l}\text { Percent- } \\
\text { age }(\%)\end{array}$ & Mean & S.D. \\
\hline 1. & $\begin{array}{l}\text { Marginal (Up to } \\
1.0 \text { ha) }\end{array}$ & 85 & 70.83 & 1.11 & 0.87 \\
\hline 2. & Small (1.01-4 ha) & 33 & 27.50 & & \\
\hline 3. & Big (above 4 ha) & 2 & 1.67 & & \\
\hline B. & Annual Income & & & & \\
\hline 1. & $\begin{array}{l}\text { Low (₹ 25,900-₹ } \\
33,280)\end{array}$ & 3 & 2.50 & & \\
\hline 2. & $\begin{array}{l}\text { Medium (₹ } \\
33,281-₹ 1,65,066)\end{array}$ & 105 & 87.50 & 99,174 & 65,892 \\
\hline 3. & $\begin{array}{l}\text { High (Above ₹ } \\
1,65,067 \text { ) }\end{array}$ & 12 & 10.00 & & \\
\hline C. & Farming experien & & & & \\
\hline 1. & $\begin{array}{l}\text { Low (up to } 17 \\
\text { years) }\end{array}$ & 10 & 8.00 & & \\
\hline 2. & $\begin{array}{l}\text { Medium } \\
\text { (between } 18 \text { to } 38 \\
\text { years) }\end{array}$ & 62 & 52.00 & 28.76 & 10.99 \\
\hline 3. & $\begin{array}{l}\text { High ( } 39 \text { years } \\
\text { and above) }\end{array}$ & 48 & 40.00 & & \\
\hline D. & Training received & & & & \\
\hline 1. & Low (Up to 5) & 42 & 35.00 & & \\
\hline 2. & Medium (6-8) & 70 & 58.33 & 706 & 204 \\
\hline & $\begin{array}{l}\text { High (More than } \\
\text { 8) }\end{array}$ & 8 & 6.66 & 7.06 & 2.04 \\
\hline$\overline{\text { E. }}$ & Credit facility rec & eived & & & \\
\hline $\begin{array}{l}\text { Sl. } \\
\text { No. }\end{array}$ & Sources & $\begin{array}{l}\text { Frequency } \\
\text { (f) }\end{array}$ & & $\begin{array}{l}\text { Percent } \\
(\%)\end{array}$ & tage \\
\hline 1. & Government & 82 & & 68.33 & \\
\hline 2. & $\begin{array}{l}\text { Commercial } \\
\text { institutions/ } \\
\text { banking }\end{array}$ & 53 & & 44.16 & \\
\hline 3. & Money lenders & 15 & & 12.50 & \\
\hline 4. & Friends/relatives & 31 & & 25.84 & \\
\hline
\end{tabular}

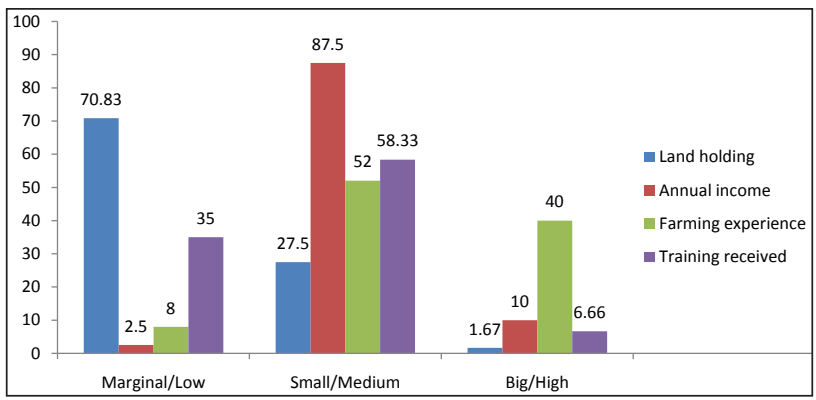

Fig. 2: Diagrammatic presentation of respondents according to their economic characteristics

\section{Psychological characteristics}

Economic motivation: The Table 3 shows that half of the respondents $(50.00 \%)$ had medium level of economic motivation. This was followed by high $(25.83 \%)$ and low $(24.17 \%)$ categories. The corresponding mean score of 24.60 indicates that the sample farmers, by and large, has medium to high level of economic motivation. The findings are in accordance with the findings of Raghavendra (2005), Balakrishnan (2001), Shashidhara (2006) and Kumar (2009).

Table 3: Distribution of respondents according to economic motivation $(n=120)$

\begin{tabular}{llllll}
\hline $\begin{array}{l}\text { S1. } \\
\text { No. }\end{array}$ & Category & $\begin{array}{l}\text { Frequen- Percent- } \\
\text { cy (f) }\end{array}$ & $\begin{array}{l}\text { Mean } \\
\text { age (\%) }\end{array}$ & S.D. \\
\cline { 1 - 4 } 1. & Low (7-20) & 29 & 24.16 & & \\
2. & Medium (21-30) & 60 & 50.00 & 24.6 & \multirow{2}{*}{5.01} \\
3. & High (31-35) & 31 & 25.84 & & \\
\cline { 1 - 4 } & Total & $\mathbf{1 2 0}$ & $\mathbf{1 0 0}$ & \\
\hline
\end{tabular}

Market orientation: The table 4 shows that average score of respondents' in market orientation is mean (24.02). Majority of the rice growers' had high level of market orientation (45.00\%) followed by medium $(38.33 \%)$ and low $(16.67 \%)$. This indicates that the sample farmers had high to medium level of market orientation. The findings are in conformity with findings of Wadkar et al. (2018).

Table 4: Distribution of respondents according to market orientation $(n=120)$

\begin{tabular}{|c|c|c|c|c|c|}
\hline $\begin{array}{l}\text { Sl. } \\
\text { No. }\end{array}$ & Category & $\begin{array}{l}\text { Frequen- } \\
\text { cy (f) }\end{array}$ & $\begin{array}{l}\text { Percent- } \\
\text { age }(\%)\end{array}$ & Mean & S.D. \\
\hline 1. & Low (6-22) & 20 & 16.67 & \multirow{4}{*}{24.02} & \multirow{4}{*}{1.92} \\
\hline 2. & Medium (23-24) & 46 & 38.33 & & \\
\hline \multirow[t]{2}{*}{3.} & High (25-30) & 54 & 45.00 & & \\
\hline & Total & 120 & 100 & & \\
\hline
\end{tabular}


Information seeking behaviour: The table 5 indicates that 100.00 per cent of rice growers' took information from only one credible source namely Krishi Vigyan Kendra for rice cultivation, while 83.33 per cent, 56.66 per cent, 10.00 per cent and 5.00 per cent of the rice growers' took information from various formal and informal sources like representative of input agencies or dealers, radio, friends and farmers of the other villages, respectively. Depending on the information seeking behaviour, respondents were categorised into three categories. The findings are in conformity with findings of Kabir et al. (2014).

Table 5: Distribution of respondents according to their Information seeking behaviour $(n=120)$

\begin{tabular}{llll}
\hline $\begin{array}{l}\text { Sl. } \\
\text { No. }\end{array}$ & $\begin{array}{l}\text { Frequen- } \\
\text { cy (f) }\end{array}$ & $\begin{array}{l}\text { Percent- } \\
\text { age (\%) }\end{array}$ \\
\hline 1. & Field officer (Agri. Dept.) & 0 & 0.00 \\
2. & SMS (Krishi Vigyan Kendra) & 120 & 100.00 \\
3. & $\begin{array}{l}\text { Representative of input } \\
\text { agencies/dealers }\end{array}$ & 100 & 83.33 \\
4. & Radio & 68 & 56.66 \\
5. & Friends & 12 & 10.00 \\
6. & Farmers of other villages & 6 & 5.00 \\
\hline
\end{tabular}

$(n=120)$

\begin{tabular}{llllll}
\hline $\begin{array}{l}\text { Sl. } \\
\text { No. }\end{array}$ & Category & $\begin{array}{l}\text { Frequency } \\
\text { (f) }\end{array}$ & $\begin{array}{l}\text { Percentage } \\
(\mathbf{\%})\end{array}$ & Mean & S.D. \\
\hline 1. & Low (1-2) & 54 & 45.00 & & \\
2. & Medium (3-4) & 60 & 50.00 & \multirow{2}{*}{3.18} & 1.38 \\
3. & High (5-6) & 6 & 5.00 & & \\
\hline & Total & $\mathbf{1 2 0}$ & $\mathbf{1 0 0}$ & & \\
\hline
\end{tabular}

Decision making ability: Table 6 shows that average score of respondents' in decision making ability was mean (33.62). Majority of the rice growers' had medium level of decision making ability $(83.33 \%)$, followed by high $(10.00 \%)$ and low $(6.66 \%)$ respectively. This indicates that the sampled farmer had medium to high level of decision making ability. The findings are in conformity with the findings of Ahmed et al. (2011).

Table 6: Distribution of respondents according to their decision making ability $(\mathrm{n}=120)$

\begin{tabular}{|c|c|c|c|c|c|}
\hline $\begin{array}{l}\text { S1. } \\
\text { No. }\end{array}$ & Category & $\begin{array}{l}\text { Frequen- } \\
\text { cy (f) }\end{array}$ & $\begin{array}{l}\text { Percentage } \\
\text { (\%) }\end{array}$ & Mean & S.D. \\
\hline 1. & Low (8-30) & 8 & 6.66 & \multirow{4}{*}{33.62} & \multirow{4}{*}{2.68} \\
\hline 2. & Medium (31-35) & 100 & 83.33 & & \\
\hline 3. & High (36-40) & 12 & 10.00 & & \\
\hline & Total & 120 & 100 & & \\
\hline
\end{tabular}

Risk orientation: Table 7 indicates that most $(45.00 \%)$ of the respondents' were found to have high risk bearing ability followed by 36.67 per cent having medium risk bearing ability while 18.33 per cent were found to have low risk bearing ability. Good level of risk bearing ability was due to good education, high level of innovation proneness and better economic condition of the respondents. This shows that they do not like situations and commitments where the chance of desired outcome is very low. The results were in conformity with the results of Kolur (2007).

Table 7: Distribution of respondents according to their risk orientation $(n=120)$

\begin{tabular}{|c|c|c|c|c|}
\hline $\begin{array}{l}\text { S1. } \\
\text { No. }\end{array}$ & Category & $\begin{array}{l}\text { Frequen- } \\
\text { cy (f) }\end{array}$ & $\begin{array}{l}\text { Percent- } \\
\text { age (\%) }\end{array}$ & Mean S.D. \\
\hline 1. & Low (6-17) & 22 & 18.33 & \multirow{4}{*}{23.3} \\
\hline 2. & Medium (18-28) & 44 & 36.67 & \\
\hline 3. & High (29-30) & 54 & 45.00 & \\
\hline & Total & 120 & 100 & \\
\hline
\end{tabular}

Innovation proneness: It is evident from Table 8 that majority $(50.00 \%)$ of the respondents belonged to medium innovation proneness category followed by high $(28.34 \%)$ and low $(21.66 \%)$ respectively. Better income, majority of them belonging to middle age category and good contact with the extension personnel are the reasons for their medium and high innovation proneness. The results were in line with the result of Reddy (2005) and Pottappa (2008).

Table 8: Distribution of respondents according to their innovation proneness $(n=120)$

\begin{tabular}{llllll}
\hline $\begin{array}{l}\text { Sl. } \\
\text { No. }\end{array}$ & Category & $\begin{array}{l}\text { Frequen- } \\
\text { cy (f) }\end{array}$ & $\begin{array}{l}\text { Percent- } \\
\text { age (\%) }\end{array}$ & Mean S.D. \\
\hline 1. & Low (5-15) & 26 & 21.66 & & \\
2. & Medium (16-22) & 60 & 50.00 & \multirow{2}{*}{19.23} & 4.47 \\
3. & High (23-25) & 34 & 28.34 & & \\
\cline { 1 - 4 } & Total & $\mathbf{1 2 0}$ & $\mathbf{1 0 0}$ & & \\
\hline
\end{tabular}

Attitude towards KVK: From the table 9, it is seen that 70.00 per cent of the respondents had medium level of attitude towards KVK training followed by high attitude $(23.33 \%)$ and low attitude $(6.67 \%)$. The calculated mean score of 34.78 indicates that farmers, on an average, had medium to high level of attitude towards KVK training programmes. The findings of the study were in agreement with the results obtained by Maraddi (2006). 
Table 9: Distribution of respondents according to their attitude towards KVK $(n=120)$

\begin{tabular}{lllll}
\hline Category & Frequency & Percentage & Mean & S.D. \\
\hline Low (Up to 20) & 8 & 6.67 & & \\
Medium (Between & 84 & 70.00 & & \\
$\begin{array}{l}\text { 21 to 40) } \\
\text { High (Above 40) }\end{array}$ & 28 & 23.33 & & \\
\cline { 1 - 3 } Total & $\mathbf{1 2 0}$ & $\mathbf{1 0 0}$ & & \\
\hline
\end{tabular}

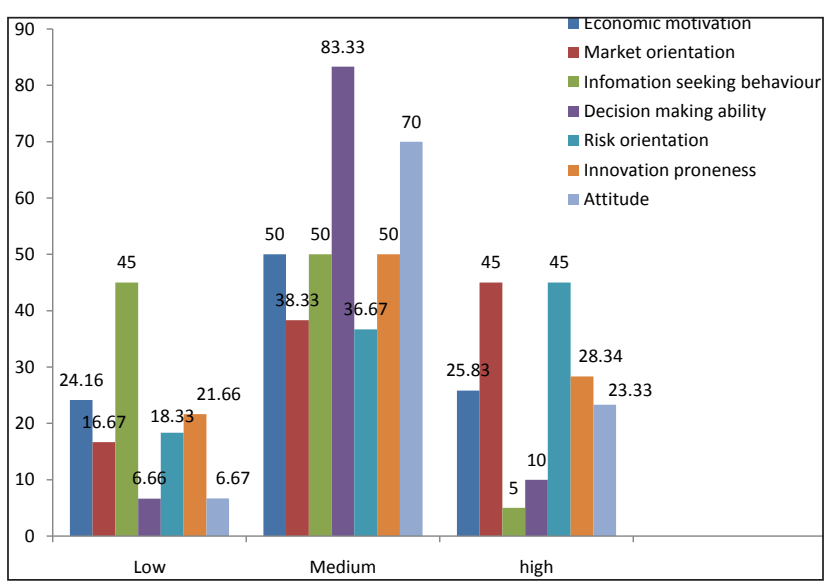

Fig. 3: Diagrammatic presentation of respondents according to their psychological characteristics

\section{Constraints faced by the respondents}

In the present study constraints refers to the limitation or hindrances perceived by the trained farmers in adoption of improved technology in their farming system. An attempt was made to find out the constraints faced by the respondents. The frequency along with the percentage indicating each of the constraints was taken into account. The highest percentage so obtained among the constraints was considered as the most important constraints accordingly. For the present study those constraints which are expressed by more than 50 per cent of the respondents is considered as the major constraints faced by the trained rice grower.

Table 10: Constraints faced by the trained farmers in rice cultivation practices

\begin{tabular}{llll}
\hline $\begin{array}{l}\text { S1. } \\
\text { No. }\end{array}$ & \multicolumn{2}{l}{$\begin{array}{l}\text { Frequency } \\
\text { (f) }\end{array}$} & $\begin{array}{l}\text { Percentage } \\
\text { (\%) }\end{array}$ \\
\hline 1. & $\begin{array}{l}\text { Inadequate availability of } \\
\text { quality seed at proper time }\end{array}$ & 115 & 95.83 \\
2. & $\begin{array}{l}\text { Lack of knowledge about } \\
\text { scientific cropping pattern } \\
\text { and cropping system and } \\
\text { their method of application }\end{array}$ & 111 & 92.50 \\
\end{tabular}

3. Non-availability of improved 105

87.50

implements and other critical

inputs such as FYM/organic

fertilizers etc.

4. Low price of product in local 92 market

5. Lack of storage and 90 marketing facilities

76.67

75.00

74.16

6. Lack of guidelines about seed 89 treatment

7. Lack of credit facilities 77

64.16

8. High cost and risk to adopt 74

61.67

improved agricultural

practices

9. Irregular supply of electric 75 power

10. Unawareness of various 68 developmental programs of the government

11. Training time was not 67 convenient 12. Lack of self-employment 65
opportunities

56.67

13. Lack of proper demonstration 65

14. Lack of transportation 63 facilities

52.50

15. Non-availability of subject 62 material at hand

51.67

Table 10 reveals that among the various problems identified by the respondents, Inadequate availability of quality seed at proper time (95.83\%), Lack of knowledge about scientific cropping pattern and cropping system and their method of application $(92.50 \%)$, Non-availability of improved implements and other critical inputs such as FYM/organic fertilizers etc. $(87.50 \%)$, Low price of product in local market $(76.67 \%)$, Lack of storage and marketing facilities $(75.00 \%)$, Lack of guidelines about seed treatment $(74.16 \%)$ were considered as the major problems as indicated by its corresponding frequency. The other problems associated were Lack of credit facilities (64.16\%), High cost and risk to adopt improved agricultural practices $(61.67 \%)$, Irregular supply of electric power $(62.50 \%)$, Unawareness of various developmental programs of the government $(56.67 \%)$, Training time was not convenient $(55.83 \%)$, Lack of self employment opportunities $(54.17 \%)$, Lack of proper demonstration $(52.50 \%)$, Lack of transportation facilities $(52.50 \%)$, Non - availability of subject 
material at hand $(51.67 \%)$ respectively. The findings are in conformity with findings of Singh et al. 2016.

\section{Suggestive measures}

In the present study, the various suggestions as expressed by the respondents were collected and arranged according to their frequency and percentage. For the present study those suggestions which are expressed by more than 60 per cent of the respondents is considered as the suggestions to solve the problems.

Table 11: Suggestions as expressed by the respondents to solve the problems

\begin{tabular}{|c|c|c|c|}
\hline $\begin{array}{l}\text { Sl. } \\
\text { No. }\end{array}$ & Suggestions & $\begin{array}{l}\text { Frequency } \\
\text { (f) }\end{array}$ & $\begin{array}{l}\text { Percentage } \\
(\%)\end{array}$ \\
\hline 1. & $\begin{array}{l}\text { Strong extension network } \\
\text { for effective transfer of latest } \\
\text { technologies }\end{array}$ & 115 & 95.83 \\
\hline 2. & $\begin{array}{l}\text { Improvement of credit and market } \\
\text { facilities and crop insurance are } \\
\text { required }\end{array}$ & 112 & 93.33 \\
\hline 3. & $\begin{array}{l}\text { Organising as many as awareness } \\
\text { and training programme towards } \\
\text { improved practices covering more } \\
\text { village in the district }\end{array}$ & 105 & 87.50 \\
\hline 4. & $\begin{array}{l}\text { To encourage the integrated pest } \\
\text { management approach for effective } \\
\text { control of pests and diseases } \\
\text { by emphasizing the need based } \\
\text { application of pesticides }\end{array}$ & 101 & 84.16 \\
\hline 5. & $\begin{array}{l}\text { Development activities are } \\
\text { required to be strengthened } \\
\text { suitably achieving growth in rice } \\
\text { productivity and production }\end{array}$ & 95 & 79.16 \\
\hline 6. & $\begin{array}{l}\text { Conduct group discussion/meetings, } \\
\text { demonstration, and on-farm } \\
\text { testing on different rice cultivation } \\
\text { practices. }\end{array}$ & 88 & 73.33 \\
\hline 7. & $\begin{array}{l}\text { Establish more storage and } \\
\text { marketing facilities }\end{array}$ & 84 & 70.00 \\
\hline 8. & $\begin{array}{l}\text { The line sowing in upland rice areas } \\
\text { through suitable seeding devices is } \\
\text { required to be made popularized for } \\
\text { desired plant population }\end{array}$ & 82 & 68.33 \\
\hline
\end{tabular}

Table 11 reveals that the main suggestions expressed by the respondents were Strong extension network for effective transfer of latest technologies, Improvement of credit and market facilities and crop insurance are required, Organising as many as awareness and training programme towards improved practices covering more village in the district, To encourage the integrated pest management approach for effective control of pests and diseases by emphasizing the need based application of pesticides. The other suggestion as expressed by the respondents to solve the problems are Development activities are required to be strengthened suitably achieving growth in rice productivity and production, Conduct group discussion/meetings, demonstration, and on-farm testing on different rice cultivation practices, Establish more storage and marketing facilities and line sowing in upland rice areas through suitable seeding devices is required to be made popularized for desired plant population respectively. The findings are in conformity with findings of Singh et al. 2016.

\section{CONCLUSION}

Krishi Vigyan Kendra is considered as the knowledge and resource center of the local areas at district level to meet the requirements of the local agro-climatic conditions. These institutions were set up to enhance the level of technical knowledge among farmers. Prof. M.S. Swaminathan aptly coined the word 'technical ability' to mean 'ability of rural people (although illiterate, otherwise) in understanding and using technical knowledge of farm science'. Such technical literacy would be imparted through work experience and farmers' training through 'learning by doing'. This calls for conscious consideration and take care on the part of extension worker and other concerned departments on training and proper management of technology in agriculture for further progress and development in rural areas.

The major findings of the present study have a measure of implications for extension workers, agricultural scientists, planners, policy makers and administrators. Some of the important implications are given below.

1. Different training programmes followed by field demonstration should be organised and imparted so that farmers develop confidence in them to take up improved methods to increase their productivity and improve their socio-economic condition.

2. Allocation of budgets under contingency head should be increased for trainings leading to increase in dimensions and numbers of KVK trainings under different thematic areas of agriculture and allied sectors. 
3. Since some of the specific practices under different major practices although very much necessary in rice cultivation were not adopted by any of the farmer under study because of socio and economic problems. Necessary technical guidance through specific training programmes followed by other extension efforts may be taken up by the, KVK, concerned line departments and other organisations on such non-adopted practices.

4. The findings also indicate that the variables such as decision making ability, risk orientation, innovation proneness, attitude towards KVK training, education, age, farming experience, training received and land holding had significant impact on rural society, there is a call for extension agencies and other departments to manipulate these crucial factors through different extension efforts and programmes.

5. The KVK staff should try to improve their job efficiency especially in ensuring that the rural youth within the KVK district could take up self-employment venture for sustainable income generation.

6. Establishment of ICT facilities for effective dissemination of information to different stakeholders including farmers may be encouraged.

7. Publication of regular and reliable farm magazine should be made available for the benefit of the farming community.

8. Non-availability of improved implements, inadequate availability of quality seeds at proper time and other critical inputs in the study area suggested that government should create adequate infrastructure facilities and arrange to supply these inputs to farmers at cheapest rates by offering stores in the villages so that farmers find them accessible at the lean period.

9. The study covered only one district of the state and therefore, its findings could be expanded to other districts of Meghalaya. Similar studies should be planned for other hill districts of the state, so that the findings of both could be used effectively for drawing generalisation of training programme on other improved agricultural practices.

\section{REFERENCES}

Ahmed, T., Hasan, S. and Haneef, R. 2011. Entrepreneurial characteristics of the Agripreneurs under the scheme of Agriclinics \& Agri-businss Centres. J. Community Mobilization and Sustainable Development, 6(2): 145-149.

Alam, M.M., Siwar, C., Murad, M.W., Molla, R.I., and Toriman, M.T. 2010. Socio-economic profile of farmer in Malaysia: Study on integrated agricultural development area in North-West Selangor. Agricultural Economics and Rural Development, 7(2): 249-265.

Balakrishnan, A. 2001. Constraints analysis of rice farmers of Thrissur district of Kerala. M.Sc. (Agri.) Thesis, Submitted to Acharya N.G. Ranga Agricultural University, Hyderabad (India).

Beerannarai, B. 1995. A study on knowledge and adoption of improved dairy practices by farmers trained by KVK, Hanumanahatti, Dharwad district. M.Sc. (Agri.) Thesis, Submitted to University of Agricultural Sciences, Dharwad (India).

Dasgupta, S. 1989. Diffusion of Agricultural Innovations in Village India, Delhi, Wiley Eastern Ltd. pp. 11-13.

Deshmukh, S. and Mane, A. 1999. Training needs of rural women in home science and agriculture. Maharashtra J. Extn.Edu., 18: 178-181.

Dubey, A.K., Srivastava, J.P., and Sharma, V.K. 2008. Attitude of Respondents towards KVK Training Programmes. Indian Res. J. Ext. Educ., 8(2\&3): 78-80.

Economic Survey 2015. Vol. 1 Government of India, Ministry of Finance, Department of Economic Affairs, Economic Division February, 2015.

Gajendra, T.H. 2012. Perspectives of farmers on effect of climate change on agriculture and livestock. M.Sc. (Agri.) Thesis, Submitted to University of Agricultural Sciences, Dharwad, Karnataka (India).

Gohain, J. 2006. Adoption of organic farming practices in vegetable crops in upper Brahmaputra valley zone (UBVZ) of Assam. M.Sc. (Agri.) Thesis, Submitted to Assam Agricultural University, Jorhat (India).

Gopalswamy, P. and Anbarashan, P. 2011. Analysing innovative sustainable practices extend and income generation in organic farming and GRA fields in Bahour, Puducherry, India. J. Development and Agric. Econ., 3(6): 252-260.

Kabir, K.H., Roy, D., Sarker, M.S., and Kuri, S.K. 2014. Information Seeking Behavior of the Farmers to Ensure Sustainable Agriculture. European Academic Research, 2(2): 3723-3734.

Kolur, M.S. 2007. A study on rehabilitant's farmers in upper Krishna project area of Bagalkot district of Karnataka. M.Sc. (Agri.) Thesis, Submitted to University of Agricultural Sciences, Dharwad (India). 
Kudamala, S., Sharma, S. and Guleria, A. 2019. SocioEconomic characteristics and problems faced by Apple cultivators under with Drip and without drip irrigation system. Eco. Affairs, 64(2): 451-457.

Kumar, G., Krishnan, B.P. and Soundaranjan, R. 2007. Socioeconomic condition of fishermen in Andaman Islands. Indian Journal of Extension Education, 43(1\&2): 99-102.

Kumar, S. 2009. A study on technological gap in adoption of the improved cultivation practices by the soybean growers. M.Sc. (Agri.) Thesis, Submitted to University of Agricultural Sciences, Dharwad (India).

Lestrelin, Guillaume, Nanthavong, Khanla, Jobard, Etienne, Keophoxay, Anousith, Lienhard, Pascal, Khambansenang, Chanxay, Castella and Jean Christophe. 2012. To till or not to till? The diffusion of conservation agriculture in Xieng Khouong Province, Lao PDR opportunities and constrainsts. Outlook on Agriculture, 41(1): 41-49.

Mangala, B. 2008. Impact of integrated farming system on socio-economic status of Bharatiya Agro-industries Foundation (BAIF) Beneficiary farmers, M.Sc. (Agri.) Thesis, Submitted to University of Agricultural Sciences, Dharwad (India).

Maraddi, G.N. 2006. An analysis of sustainable cultivation practices followed by sugarcane growers in Karnataka. Ph.D. Thesis, Submitted to University of Agricultural Sciences, Dharwad (India).

Moulasab, I. 2004. A study on knowledge and adoption of improved cultivation practices by mango growers of North Karnataka. M.Sc. (Agri.) Thesis, Submitted to University of Agricultural Sciences, Dharwad (India).

Parvathamma, T. 2012. Impact of Sujala watershed project on socio-economic status of women beneficiaries in Chitradurga District, Karnataka. Ph.D. Thesis, Submitted to University of Agricultural Sciences, Bangalore (India).

Pottappa, K. 2008. Knowledge and adoption of potato growers in Chikkaballapur district- A case study. M.Sc. (Agri.) Thesis, Submitted to University of Agricultural Sciences, Bangalore (India).

Raghavendra, R. 2005. Knowledge and adoption of recommended cultivation practices of cauliflower growers in Belgaum district of Karnataka. M.Sc. (Agri.) Thesis, Submitted to University of Agricultural Sciences, Dharwad (India).

Reddy, V.S. 2005. A study on knowledge, extent of participation and benefits derived by participant farmers of the watershed development programme in Raichur district of Karnataka state. M.Sc. (Agri.) Thesis, Submitted to University of Agricultural Sciences, Dharwad, Karnataka (India).

Reddy, V.S. 2006. Knowledge and adoption of integrated pest management practices among vegetable growers of Gadag district in North Karnataka. M.Sc. (Agri.) Thesis, Submitted to University of Agricultural Sciences, Dharwad (India).
Roy, M.L., Chandra, N., Kharbikar, H.L., Joshi, P. and Jethi, R. 2013. Socio-economic status of Hill Farmers: An exploration from Almora district in Uttarakhand. International Journal of Agriculture and Food Science Technology, 4(4): 353-356.

Saikia, H., Changmai, H.K. and Bhomick., B.C. 2014. An analysis of Share Cropping in Rice Cultivation- A case study in Karimganj district of Assam. Eco. Affairs, 59(3): 459-463.

Samantha, R.K. 1977. A study of some agro-economic, sociopsychological and communication variables associated with repayment behaviour of agricultural credit users of nationalized banks. Unpublished Ph.D. Thesis, Submitted to Bidhan Chandra Krishi Viswa Vidyalaya, Nadia, West Bengal (India).

Shashidhara, K.K. 2006. A study on management of ecofriendly practices by vegetable growers of North Karnataka. Ph.D. Thesis, Submitted to University of Agricultural Sciences, Dharwad (India).

Singha, A.K. 1991. A study on determinant of entrepreneurial behaviour in adoption of rice cultivation by the farmers of Kachar district of Assam. M.Sc. (Agri.) Thesis, Submitted to Department of Extension Education, Assam Agricultural University, Jorhat (India).

Singha, A.K. 2000. A study on the management of forest resources by the people of forest villages under the Golaghat forest division of Assam. Ph.D. Thesis Submitted to Department of Extension Education, Assam Agricultural University, Jorhat (India).

Singha, A.K., Bordoloi, R., Jat, P.C., Singha, J.K., and Devi, M. 2016. Socio-economic profile of the common adopters of improved practices of crops and livestock enterprises and their problems and suggestive measures - A case study in adopted and non-adopted villages in North Eastern India. Eco Affairs. 61(2): 289-298.

Sridhara, K. 2002. An evaluative study of watershed programme in pavagada taluk of Tumkur district in Karnataka. M.Sc. (Agri.) Thesis, Submitted to University of Agricultural Sciences, Dharwad (India).

Sulthana, T.D. 2001. Impact of selected non-government organisation on rural women. M.H.Sc. Thesis, Submitted to University of Agricultural Sciences, Dharwad (India).

Tani Net 2000. Second Quarter, DAGS Report, Tani Net Project, UKM-MTDC Bangi, Selangor, Malaysia.

Trivedi, G. and Pareek, U. 1964. Manual of the Socio-Economic status Scale (Rural), Manasayan, 32, Netaji Subhas Marg, New Delhi-6.

Wadkar, J.R., Kamble, V.B., Desmukh, N.D., and Wangikar, S.D. 2018. Economic Performance of Tissue Culture and Conventional Banana Growers. International Journal of Current Microbiology and Applied Sciences, ISSN: 2319-7692 Special Issue-6 pp. 2464-2472. 